\title{
An Overview of Citizen Satisfaction with Public Service: Based on the Model of Expectancy Disconfirmation
}

\author{
Rashmi Chatterjee*, Rathny Suy \\ School of Public Affairs, University of Science and Technology of China, Hefei, China \\ Email: ^rashmi@mail.ustc.edu.cn
}

How to cite this paper: Chatterjee, R. and Suy, R. (2019) An Overview of Citizen Satisfaction with Public Service: Based on the Model of Expectancy Disconfirmation. Open Journal of Social Sciences, 7, 243-258. https://doi.org/10.4236/jss.2019.74019

Received: March 18, 2019

Accepted: April 16, 2019

Published: April 19, 2019

Copyright (อ 2019 by author(s) and Scientific Research Publishing Inc. This work is licensed under the Creative Commons Attribution International License (CC BY 4.0).

http://creativecommons.org/licenses/by/4.0/

\section{(c) (i) Open Access}

\begin{abstract}
The primary objective of this article is to gauge the satisfaction of the citizen with the help of expectancy disconfirmation model (EDM) and discover areas for future research dependent on this model. This study examines expectancy disconfirmation model utilized in government sector to measure citizen satisfaction reported in literature since 2004. This review will attempt to identify the linkage between each of the studies and figure out the gap for upcoming research. Review of entire past researches revealed that satisfaction is a function of expectation, perceived service quality and disconfirmation (expectation-perception about service quality) of beneficiaries. The expectation intended to a particular service is changing with the passage of time. Growth of literature in the domain of citizen satisfaction seems to build up consecutively providing a continuous learning from the findings of earlier researches. This study drew a new dimension to the practitioners in this specific field.
\end{abstract}

\section{Keywords}

Citizen Satisfaction, Expectation, Expectancy Disconfirmation Model, Public Sector, Service Quality

\section{Introduction}

Public management has given emphasis to determine the government performance, which particularly focuses to measure the outcomes. However objective measures are not always appropriate to recognize the outcomes of government services [1]. To resolve this issue emphasis has given to connect internal activities along with the outcome which is appreciated by common people [2]. It would help to enhance effectiveness, efficiency of public services through reallo- 
cate resources and reorganize the process of service delivery [3]. Consequently citizen satisfaction with the public services has emerged as an area of interest for the academicians and managers in the subject of public management. Citizen satisfaction index is an instrument to identify the view of common people about their living area [4]. The extent of citizen satisfaction is directly linked with the outcome of the administrative performance which can stimulate the reform in the government sector [5].

Existing literature has recognized the use of survey of citizen in assessing performance of local government [6] [7]. Citizen satisfaction survey is the commonly used measures in assessing the outcome of the action taken by local government. Satisfaction survey plays a vital role in procurement of resources, and performance improvement, which help the local government to be more proactive towards the needs of the citizen that will enhance people's trust in government [8].

The remainder of the article is arranged as follows: at first each term is defined, and then importance of the study is highlighted. Next part describes the background of the theory. Then the summery of the earlier studies linked with this model is summarized. Finally the conclusion and prospects are provided.

\section{Definitions of the Terms}

\subsection{Concept of Satisfaction}

Satisfaction can be termed as a post consumption evaluation of quality of services [9]. It is a mental state that arises after encountering a service and contrasting that with previously hold experiences [10]. Therefore satisfaction is positively related with perception about the performance. Along with the managerial measures, satisfaction is also used as a standard of service performance [11] [12]. Customer satisfaction is a familiar concept in marketing field. In consumer behavior literature it can be interpreted as the alternative among substitutes and brands. Expectations are regarded as the principal aspect of satisfaction studies. Expectations are created prior to actual experience about any goods or services and compare against the perception of performance. Expectations and perception individually and collectively influence the satisfaction. For the sustainable growth every institute should focus on customer satisfaction as the satisfied customer can spread their opinion (by WOM) to many people which is beneficial for organization/institute [13]. Citizens' satisfaction with the public goods or services also gets the attention of public administrator or manager in late 1990s or early $20 \mathrm{~s}$ particularly for OECD countries [14] [15]. Citizen satisfaction plays a crucial role to realize the requirement of common people.

In the beginning of 1980 or late $70 \mathrm{~s}$, elements of citizen satisfaction with civil services have been explored which include the relationship among demographic traits (age, income, gender, race etc.) and satisfaction. For instance, the outcome of some study suggested that Blacks were tend to be less satisfied with government services [16], suggesting, that jurisdictions with more black residents pro- 
vide lower quality services or demographic characteristics show diverse levels of demand for services. A gap has been recognized between subjective and objective method of evaluation of governmental services. To bridge this gap academician concentrated on the effect of perceived service quality, instead of objective quality, as a factor of satisfaction [17] [18]. Dissatisfaction linked with the perceived performance is considered as complain of citizen towards their local administration for being not up to the mark [12].

\subsection{Concept and Role of Expectation to Form Satisfaction}

The effect of consumer expectations has been well established with the products of private organization. However public organization has recognized the value of it in the beginning of $20^{\text {th }}$ century with the work of [17]. Expectations can be termed as future intended subjective attitudes and viewpoint which includes a wide variety of things [19]. Citizen expectations about public services have an imperative role on satisfaction judgment and their political voice which includes voting behavior [11] [12] [17] [19]-[25]. According to James, expectations are the 'judgments of what individuals or groups think either will or should happen under particular circumstances'. Expectations can be categorized in two ways: 1) positive expectation and 2) normative expectations. Positive expectations are defined as citizen's view about what will be the performance of a service whereas normative expectations are citizen's assumption about what service performance should be. Thus normative expectations specify that civilian have observation about what is realistic and desirable. Positive expectations not always bring out those results that individual consider as desirable likewise normative expectations not lead to those outcome that citizen assume as important. Both expectations have their own influence to outline satisfaction judgment with community services. Recently academicians have considered the impact of positive expectation on the satisfaction with the public services [12] [17] [20].

Numerous factors help to formulate the expectations in the private and public sector services. Impact of expectations has been recognized in the services of private organization [26]. Oliver has explained the influence of informal communications (WOM), personal needs and past experience to form expectations about the perception of services. In case of public sector along with previous mentioned factors there are some other parameters that have strong impact to form expectations in public services. These factors are the amount of tax paid, availability of resources and other provisions related to service delivery. In this background provision of information also have a major role. Generally citizens are not well aware about all the governmental policies and performance [27]. All this information may originate from different sources like the media, personal experiences, WOM, service provider themselves [28] [29]. The information is particularly important for those services which are not directly experienced by citizen or used very frequently. According to James \& Wilson [30], the information about the excellent performance would increase citizen satisfaction whereas 
satisfaction would decrease with the information of poor performance. In 2011, James has examined that the positive expectations would tend to increase with the information of excellent performance. Thus the public administrator and politician can easily manipulated expectations through information to enhance citizen satisfaction with government services.

\subsection{Definition and Functions of Service Quality to Form Satisfaction}

The performance of any institution is significantly relying on the standard of services it gives to its clients/stakeholders. Generally after purchase customers judge the perceived services in contrast with their expectations. On the basis of this comparison customers will form their satisfaction judgment about the standard of perceived service. Therefore the conception of service quality is interlinked with the idea of satisfaction though both are different [31]. According to some researchers customer satisfaction is short term as it is service specific experience whereas the judgment of quality is long term because it's a cognitive process. Service quality can be defined as expectations and perception of a customer related to a service [32]. Quality of a service can be assessed in two steps-1) the way service is rendered and 2) the result of the rendered service [33]. Gronroos [34] have identified two areas of service quality namely-the technical quality and functional quality. Technical quality is concern about what consumer receives while functional quality emphasizes about the process (how).

To fully understand the component of service quality for satisfaction nineteen conceptual models were introduced by researchers within 1984 to 2003 [35]. These models are vital for perceived the components related to service quality and the inter relation among those components. Due to diverse nature of service quality academicians have divided these models into two schools which consist with the school of America and the school of Northern Europe [36]. Quality government services can be assessed by the experience and satisfaction of the citizen [37]. Satisfaction can be obtained by innovation as along with improved service quality.

\subsection{Concept of Disconfirmation}

In the literature of consumer behavior disconfirmation is described as discrepancy or gap among expectations and perceived performance [38]. Based on the outcome disconfirmation can be positive or negative. When the perceptions about the performance go beyond the expectation level it will lead to positive disconfirmation. In contrast, when performance cannot reach up to expectation level it gives rise to negative disconfirmation. The SERVQUAL model is established on the concept of disconfirmation [32]. In marketing the influence of disconfirmation to shape satisfaction has been recognized for long ago [10] [39]. In the beginning of $20^{\text {th }}$ century the effect of disconfirmation has been identified in public management and the results are similar with the result of private sec- 
tor. The result suggested that positive disconfirmation gives rise to high satisfaction [11] [17] [20].

\section{Importance of the Current Study}

After the development of New Public Management (NPM), Performance measurement in government sector has been adopted as a vital component around the world. In 1992 Osborne and Gaebler first time introduced the idea of "Reinventing Government" where they considered citizen as consumer. Here performance is calculated by effectiveness of service delivery and the improvement is indicated by increased level of satisfaction of beneficiaries. Involvement of common people in the evaluation is essential to build a strong relationship between government and citizen through trustworthiness. Amid last decades public sector has changed radically after introduction of citizen centric approach. The main changes include decentralization and citizen participation in decision making process. In this aspect citizen satisfaction survey become an inevitable tool to measure the performance of government. Studies suggested that the performance measurements fail to achieve its goal if the need of citizen has not been incorporated in that. As a result the process will become less effective for the governmental decision making [40]. Akgul, [41], rightly explained that without incorporating the expectation and perceptions of beneficiaries' performance measurement cannot be achieved. Satisfaction is a mixture of cause and effect of various construct. In literature service specific expectations and disconfirmation is pointed out as two major components for the development of satisfaction judgment [10]. The EDM is the most suitable to describe these two constructs. This model has ruled private-sector to investigate consumer satisfaction for ages, however in recent times it has been connected with citizen satisfaction with services of local government by Van Ryzin [17]. This study will give the idea about how this model has modified in the field of public service over the progress of time and the applicability of this model in different governmental level (local government, state government, central government). This article also briefly address how the outcome vary with the same model with different context. Therefore this study can summarize the results of earlier studies and help to identify the loopholes for future development.

\section{Theoretical Background}

Expectancy disconfirmation is a psychological theory, commonly used in marketing, especially in consumer behavior to determine the post purchase satisfaction of purchaser/buyer. Expectations-confirmation theory proposes that expectations, along with perception of performance, shaped post-purchase satisfaction. This relation is mediated through disconfirmation (either positive or negative) connecting expectations and performance. As indicated by this theory, individual formed their judgment about any product or service; with already possess set of beliefs with respect to the attributes or benefit of that product or 
service offered [10]. Actual, performance of any item can be uncovered simply after the utilization which is contrasted against earlier desire level (prior expectation level). In literature, the gap between expectations and perceived/actual performance is termed as disconfirmation of expectation. Disconfirmation can be positive, when expectation exceeds performance or negative, when performances not reach up to the level of expectation. Role of disconfirmation as an indicator of client satisfaction have been proved in different studies of consumer behavior [10] [39]. The expectation level serves as a ground to form disconfirmation. Positive disconfirmation results in satisfaction, while the negative disconfirmation decreases it. Oliver has identified disconfirmation as the crucial element as expectation may change over the progress of time.

The above figure demonstrates the performance-based model of expectancy disconfirmation, which is stable with the experimental along with the theoretical research in the practice of business literature. The relationship within the different variables (mentioned below) demonstrated in Figure 1 provides an insight about the important hypotheses associated with this model and its implication for the analysis of citizen satisfaction in public sectors.

The above diagram (Figure 1) demonstrates the relationship among the key variables of EDM. It is hypothesized that high expectations give rise to more negative disconfirmation (path A), on the other hand link among performance and disconfirmation (link B) represents that high performance results in more positive disconfirmation. Disconfirmation, in turn, is positively influenced to frame satisfaction judgment (link C). It indicates that positive disconfirmation (beyond expectations) generates higher level of satisfaction, whereas negative disconfirmation (expectations going down) decreases the satisfaction level. Finally, expectations and performance are also believed to be positively interlinked (link D), particularly in case of empirical research, yet the particular direction of this relationship has not been specified yet. All these relationships in the figure principally describe the expansion of basic EDM [10] [38]. With the progress of time the core model has been refined with other directions that can work parallel in conjunction with the fundamental relations of EDM. Link E shows performance positively connected with satisfaction. It indicates that performance is a preliminary element which can influence the satisfaction beyond varying expectation

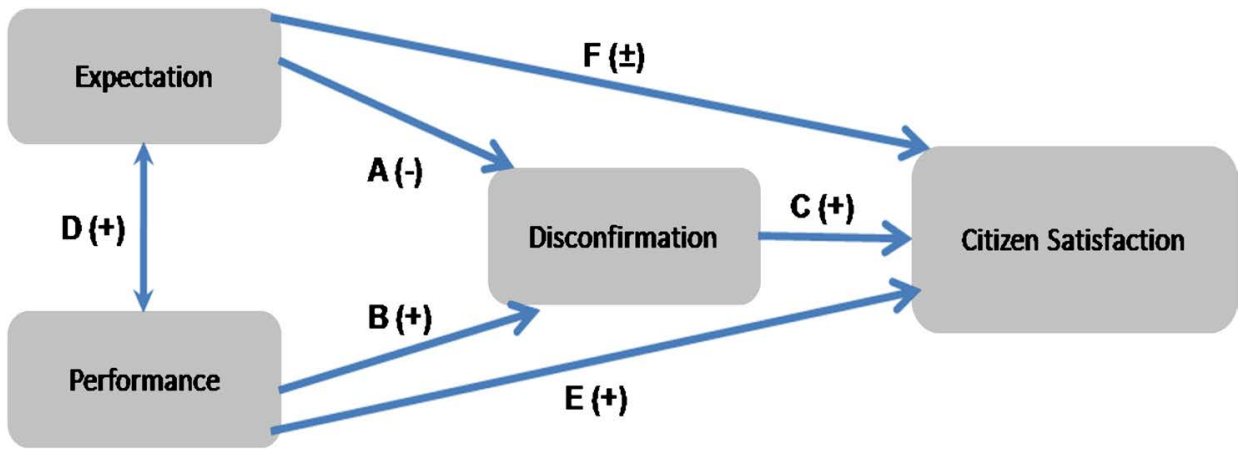

Figure 1. Expectancy disconfirmation with performance model (adopted from Ryzin, 2004). 
level of individual. The direct and combine effect (with disconfirmation) of performance on satisfaction has been explored in literature [15]. To assess citizen satisfaction if the link E appears relatively stronger, then it would propose that the formation of satisfaction is basically based on execution of performance only without considering the outcome of prior expectations. The direct impact of expectations on satisfactions is shown by the link F. Expectations can influence satisfaction when people are unable to evaluate the service performance of LG directly then the evaluation is done on the basis of previously hold expectation for reasons of dissonance reduction or ego defensiveness [38]. As the quality of services provided by LG is strongly correlated with the view of citizen or individual's political attitudes [42], so therefore, individual can anticipate that this effect of assimilation would contribute to determine citizen satisfaction. This effect could be negative [21] which is aligning with fundamental process of expectancy-disconfirmation as a means of performance perception. However, in some studies direct positive effect of expectations [17] has been reported in literature. These two results are counter balancing each other apparently. As people apply the expectations as a referent point to form judgment about satisfaction and hence this satisfaction rating is attached with this baseline specifically it is relevant when evaluation is difficult or ambiguous [39].

\section{Previous Study Based on This Model}

Variables of this framework have been theoretically constructed and empirically verified for long ago in the literature of consumer behavior [10] [39]. In the year 1965, Cardozo has pointed out that expectation and effort exerted to obtain a certain product are the key factors to form satisfaction judgment among customer as both of these two variables can be influenced or manipulated up to a certain extent by external factors like advertisement, sales promotion etc. In this study the relationship among those variables were well described by means of two psychological theories, namely contrast theory and theory of cognitive dissonance. According to contrast theory the difference among individual's expectations and perception leads to magnify the disconfirmation. It indicates that an individual when receives a product/service less valuable than expected then it will amplify this variation between the product/service received and the product/service expected. However, according to Festinger's theory of cognitive dissonance individual try to find uniformity among their cognitions (attitude, belief, opinion etc.). If any inconsistency happens then something should be done to eradicate it. For instance if someone expected a premium product and received an inferior product instead, then this disparity will leads to cognitive dissonance. This dissonance will persist as far as the opinion about the perceived quality alters.

Relationships between individual's attitude, expectations, disconfirmations and satisfaction have been tested by Oliver in the year of 1980. In this study the combine effect of expectation and disconfirmation is elucidated via Helson's 
adaptation theory (1948). According to this theory as expectations are considered as a referent point for satisfaction judgment so it acts as stimuli in the background of an adopted standard. This established standard is a consequence of individuals' perceptions; psychological and physiological character. Once the adaptation level is formed it guides to evaluate either positively or negatively from individual's original position. A gap between adaptation level and actual experience (disconfirmation) establish the measure where the assessment will deviate from adaptation level. This assessment becomes revised adaptation level for further evaluation process.

Van Ryzin has first proposed this model with a broad range of civil services by the survey of the people in New York City to find out satisfaction of common people with the services of urban areas in the year of 2004. In this study expectations specifically the disconfirmation of expectation have considered first time as a casual factor of citizen satisfaction with the feature of urban services. Disconfirmation was calculated by the difference between perceived quality of local services and expectation (on a 10 point scale where 1 means "very poor" 10 means "very good in case of perceived quality and "very low" to "very high" for expectation). The result indicated that all the three variables (expectation, performance and disconfirmation) have significant effect on overall satisfaction. Disconfirmation exerted strongest effect on satisfaction. However both expectation and perceived performance had positive effect on satisfaction. The effect (both direct and indirect) of expectation was minimal. So it is confirmed that higher the expectations from the government services will generate higher satisfaction.

Taking this research in next level Ryzin used 2003 online data of a nationwide sample of adults to observe the effect of both perceived and subtractive disconfirmation. In this study three different aspects have been tested. The first stage was similar to the previous study where the effect of subtractive disconfirmation was observed and results were almost in line with the prior study. But the strength of the relationship among expectations and satisfaction was decreased than in the former study. So it is proved that subtractive disconfirmation is a determinant of citizen satisfaction. In the second phase, the subtractive disconfirmation variable was replaced by perceived disconfirmation. Perceived disconfirmation was measured directly asking respondents to what extent government services had turn down or surpassed their expectations. The outcomes indicated that the perceived disconfirmation had less but a significant influence on satisfaction. The relationship between expectations and disconfirmation was insignificant in this stage. Still, the model was able to explain the variance which was lesser than the first model. Finally, in the third model both perceived disconfirmation and subtractive disconfirmation have been incorporated. It was predicted that "subtractive" disconfirmation exert its influence on satisfaction via "perceived" disconfirmation. The results suggested that subtractive disconfirmation had a positive effect on perceived disconfirmation and satisfaction as well. Perceived performance exerted a strong positive effect on subtractive disconfir- 
mation as well as a strong positive direct effect on satisfaction. But, the linkage between expectations and satisfaction was minimal unlike the other two models. In this model the positive effect of expectation through perceived disconfirmation was counterbalance by a similarly negative influence through subtractive disconfirmation.

Roch and Poister followed the same route of investigation with randomly selected 744 residents of Georgia. In this study the impact of perceived disconfirmation on satisfaction with public services has been analyzed with three different services of LG instead of full range of public services. This includes police service, residential refuse collection and the public school. Here the expectations are measured for each service with the help of two dummy variables 1) performance higher than expectations and 2) performance does not meet expectations. The result signified that satisfaction is positively linked with perceived performance. The outcome of this investigation was lending to further verification of the hypothesis related to EDM.

In 2007, Ryzin [43] has developed a conceptual model to correlate the objective measure of performance with the subjective measure of governmental services. In the objective measure the role of exogenous variable is also revealed. This model has explained with the help of expectancy disconfirmation model and American Customer Satisfaction Index (ASCI). From this study it is confirmed that citizen can rate appropriately those public services which is frequently consumed. This study also addresses the political behavior of citizen by incorporating overall citizen satisfaction with trust and other consequences mentioned in the EVLN (Exit, Voice, Loyalty, Neglect) model. The result indicated that satisfaction is directly related to trust and inversely linked with the moving intention from the jurisdiction. So the future behavior can be predicted from this study.

Then James has tested this model with the data collected from survey of 4,067 citizens from England. The result showed that disconfirmation was directly linked with the satisfaction for overall local services along with refuse collection. This research verified the EDM with subtractive disconfirmation (anticipated performance minus expectations). The expectation was connected in reverse way to satisfaction with a broad range of local services. This result was contradicting the result of former study of Van Ryzin. Effect of perceived performance was not confirmed in the model because the survey data exclude the measure of perceived quality. However, the researcher had incorporated objective measures as controls for performance and exhibited strong positive impacts on satisfaction.

Poister \& Thomas applied EDM beyond services of local government to the service of state government particularly in highways of Georgia. The model was used in three areas of this particular service. Namely the services are-1) condition of the road and the quality of ride 2) congestion and traffic flow and 3) safety on high ways. A new variable i.e. grade was added which was not incorporated in earlier study on this model. This new variable integrated as an evalua- 
tive component to assess the quality of service of each part of high way services. The outcome was strongly associated with EDM. The effect of expectation on satisfaction was similar with James study. However, the influence of performance and grade were relatively stronger (positive) than the (negative) effect of expectation.

Hietbrink et al. [44] has related expectancy disconfirmation model with satisfaction of road construction and maintenance project. They investigated the role of information, process and results along with expectation and experience (perceived performance) to develop satisfaction judgment. The result indicated that there was no relation among the expectation and $\mathrm{n}$ satisfaction with information provided by road agencies. Three aspects of satisfaction were jointly influenced overall satisfaction where outcome played dominant role. This investigation helps to realize that as the experience of stakeholders regarding road maintenance (road to be improved) deviated from their initial expectation, it enhanced satisfaction. So, an inverse correlation found among expectation and satisfaction. Once again it proves the outcome of James study. Results are consistent with the model.

Morgeson in the year of 2012 has verified this model in the context of federal government in US and compare the results with the studies of local government. The author expanded the model by some variables which have direct effect on expectations of citizens. The variables include trust, political orientation and party identification. The findings revealed that the model is suitable for federal government as well. A stronger link was observed between performance and satisfaction in case of federal government while disconfirmation exerted a strong effect on satisfaction with local government services. Prior expectations had strong influence towards the performance of the central government which resulted in more satisfied citizen. The study also exhibited the positive role of trust to shape the expectation judgment of individual.

In the year of 2013, Van Ryzin has experimentally tested the theory of expectancy disconfirmation in public management whereas all the previous study reported in the literature was observational study relying on survey data (except James study, 2011). This study helps to understand the direction and magnitude of the fundamental relationship among the key variables (expectations, performance, and disconfirmation) of the theory with the help of experimentally manipulated the dependent variables which were considered as endogenous variables in earlier studies. In this research the data was analyzed with traditional regression method along with path (mediation) analysis which was also utilized in prior study to minimize methodological problem (mentioned by Bullock, Green, \& Ha, 2010; Imai et al., 2011) to completely recognize mediation effect. The conclusion of this study is align with EDM and also with the preceding studies. The findings also revealed that the expectations do not exert any influence on satisfaction. The indirect negative effect of expectations is counterbalance by the direct positive effect.

Very recently, in a qualitative study Zhu et al. [45] have explained the impact of macro environmental variables in the process of service delivery in cross-national 
aspect through the use of expectancy disconfirmation theory. Macro environmental factors considered in this study include culture, national endowments, intensity of competition, regulatory institutions, degree of globalization and political background of the certain countries. This work illustrates why and how the expectations, perceived performance and satisfaction differ among different countries within different markets by the effect of disconfirmation. Service providers' perspective, especially how service providers' expectations vary along with the culture has been explored in this article.

The key findings and limitations of all the studies in the public sector depending on this particular model is summed up below in Table 1 .

\section{Concluding Remarks}

This review has provided a brief idea about citizen satisfaction with the public services in light of expectancy disconfirmation model. This model provides valuable information about the relationship among expectations, perceived service quality/performance, disconfirmation and satisfaction. The present study contributes in terms of establishing the relationship among the previous studies which address the different research problem. The results are summarized in the tabular form (see Table 1). From this study it is observed that development of this model in the field of public administration is relatively new. This study emphasizes how the model has relevant in overall services as well as specific service areas with different governmental (local government, state government, federal government) context.

From this article it is clear that expectations have contradictory effect (either positive or negative) on satisfaction in different studies. It may be because expectations can change over time; different measures are available for expectations. To clearly realize the nature and effect of expectations more studies are required about the antecedents of expectations and instead of single item measure multiple items should be incorporated to increase the reliability. This study clearly highlighted the following research aspects in public management-

- Utilize the expectancy model with all level of governments.

- Extension of the model with the progress of time.

- Role of subtractive as well as perceived disconfirmation has been tested.

However as this model is relatively new in public sector so limited studies are available in this context which may restrict the current study to completely unfold the different aspects of this model. This study observed that the model has been applied and tested in the context of developed countries. Future study can be focused on developing country to understand the applicability of this model and the results can be compared with existing studies. In upcoming times the model can be expanded with different sets of variables like transparency, trust etc. which have direct effects on satisfaction. All the studies have tested the model with single item except the performance variable. So, upcoming study can also focus on this aspect. 
Table 1. Summery of study based on expectancy disconfirmation theory in public sector.

\begin{tabular}{|c|c|c|c|}
\hline Author (year) & Contribution & Key findings & Limitations \\
\hline Ryzin (2004) & $\begin{array}{l}\text { First time applied the model of } \\
\text { expectancy disconfirmation on } \\
\text { citizen satisfaction with public } \\
\text { services, i.e. in the field of public } \\
\text { management. }\end{array}$ & $\begin{array}{l}\text { Expectations and disconfirmation played } \\
\text { a dominant role to form satisfaction with } \\
\text { the quality of public service. }\end{array}$ & $\begin{array}{l}\text { Expectations were measured with } \\
\text { previous experience that can give } \\
\text { rise to bias result. Direct measure } \\
\text { of disconfirmation was absent. }\end{array}$ \\
\hline Ryzin (2006) & $\begin{array}{l}\text { Two alternative methods } \\
\text { (perceived \& subtractive } \\
\text { disconfirmation) were utilized to } \\
\text { measure disconfirmation. }\end{array}$ & $\begin{array}{l}\text { With the rise of expectation perceived } \\
\text { (negative) disconfirmation will decrease } \\
\text { which is completely opposite for } \\
\text { subtractive disconfirmation. }\end{array}$ & $\begin{array}{l}\text { Role of expectation to form } \\
\text { disconfirmation was not clear as it } \\
\text { depend on how disconfirmation is } \\
\text { measured. }\end{array}$ \\
\hline $\begin{array}{l}\text { Roch \& Poister } \\
(2006)\end{array}$ & $\begin{array}{l}\text { Relationship among perceived } \\
\text { disconfirmation and satisfaction } \\
\text { is examined with three specific } \\
\text { services of local government. }\end{array}$ & $\begin{array}{l}\text { Disconfirmation plays the key role to } \\
\text { form satisfaction judgment with public } \\
\text { services. However, expectations and } \\
\text { perceived service quality also have } \\
\text { independent impact on satisfaction. }\end{array}$ & $\begin{array}{l}\text { The study is confined in only one } \\
\text { state focusing with three service } \\
\text { areas. So the result may vary across } \\
\text { state and with other sets of services. }\end{array}$ \\
\hline Ryzin (2007) & $\begin{array}{l}\text { Conceptual framework has formed } \\
\text { to link the objective and subjective } \\
\text { measure of performance along with } \\
\text { behavioral intention of citizen. }\end{array}$ & $\begin{array}{l}\text { The conceptual framework is explained } \\
\text { with the help of ACSI model, EVLN } \\
\text { model and Expectancy disconfirmation } \\
\text { model. }\end{array}$ & $\begin{array}{l}\text { Influence of demographic variable } \\
\text { to form satisfaction has not } \\
\text { explored. }\end{array}$ \\
\hline James (2009) & $\begin{array}{l}\text { Role of expectation disconfirmation } \\
\text { and expectation anchoring were } \\
\text { explained to form satisfaction or } \\
\text { dissatisfaction judgment. }\end{array}$ & $\begin{array}{l}\text { Disconfirmation is directly (positively) } \\
\text { linked with predicted probability of } \\
\text { satisfaction and inversely connected to } \\
\text { dissatisfaction. }\end{array}$ & $\begin{array}{l}\text { The relationship among objectively } \\
\text { measured performance and } \\
\text { satisfaction or dissatisfaction was } \\
\text { not proved. }\end{array}$ \\
\hline $\begin{array}{l}\text { Poister \& Thomas } \\
\text { (2011) }\end{array}$ & $\begin{array}{l}\text { Applied this model in state } \\
\text { government on the motorist's } \\
\text { satisfaction with the different } \\
\text { aspects of high way. The model is } \\
\text { also expanded with a new } \\
\text { variable called grade. }\end{array}$ & $\begin{array}{l}\text { Influence of grade and perceived } \\
\text { performance is stronger than the negative } \\
\text { effect of expectation on satisfaction. }\end{array}$ & $\begin{array}{l}\text { Formation of expectation was not } \\
\text { mentioned. }\end{array}$ \\
\hline $\begin{array}{l}\text { Hietbrink et al. } \\
\text { (2012) }\end{array}$ & $\begin{array}{l}\text { Applied this model to assess } \\
\text { satisfaction with public sector } \\
\text { project. }\end{array}$ & $\begin{array}{l}\text { Satisfaction with process, outcome and } \\
\text { information jointly formed overall } \\
\text { satisfaction. }\end{array}$ & $\begin{array}{l}\text { The result of this study was based } \\
\text { on small amount of data. }\end{array}$ \\
\hline Morgeson (2012) & $\begin{array}{l}\text { Tested the model in the context } \\
\text { of federal government and } \\
\text { expand the model with the } \\
\text { antecedent of expectations which } \\
\text { include party id, political } \\
\text { ideology and trust. }\end{array}$ & $\begin{array}{l}\text { Trust has positive influence to form } \\
\text { expectations. The effect disconfirmation } \\
\text { on satisfaction is stronger in local } \\
\text { government whereas effect of } \\
\text { expectations and performance and from } \\
\text { performance to satisfaction is stronger in } \\
\text { federal government framework. }\end{array}$ & $\begin{array}{l}\text { The study was conducted with } \\
\text { those citizens who have } \\
\text { communicated with federal } \\
\text { government within a } \\
\text { defined/narrow span of time. }\end{array}$ \\
\hline Ryzin (2013) & $\begin{array}{l}\text { Experimentally test the theory of } \\
\text { expectancy disconfirmation with } \\
\text { the public service (street cleanliness). }\end{array}$ & $\begin{array}{l}\text { Expectation exerted little or no net effect } \\
\text { on satisfaction. }\end{array}$ & $\begin{array}{l}\text { As the street cleanliness is clearly } \\
\text { visible, so the effect of prior } \\
\text { expectations was not clear. }\end{array}$ \\
\hline Zhu et al.(2018) & $\begin{array}{l}\text { The theory was applied in cross } \\
\text { country context in the field of } \\
\text { service delivery. Expectations of } \\
\text { service providers have taken into } \\
\text { consideration in this study. }\end{array}$ & $\begin{array}{l}\text { The study explained how the effect of } \\
\text { disconfirmation on expectations, } \\
\text { perceived performance and satisfaction } \\
\text { differ across various countries within } \\
\text { different markets. Effects of different } \\
\text { cultures on the above mentioned } \\
\text { variables were well described. }\end{array}$ & $\begin{array}{l}\text { The study has limited only in two } \\
\text { service sectors (tourism and } \\
\text { hospitality). }\end{array}$ \\
\hline
\end{tabular}




\section{Acknowledgements}

The authors would like to acknowledge Professor Song Wei, for his support and motivation. Especial thanks are also given to the CAS-TWAS Presidents' Fellowship for financial support. In addition, the authors would like to thank the anonymous reviewers and the academic editor of this journal for their valuable comments and suggestions which have substantially improved the manuscript.

\section{Conflicts of Interest}

The authors declare no conflicts of interest regarding the publication of this paper.

\section{References}

[1] Holzer, M. and Yang, K. (2004) Performance Measurement and Improvement: An Assessment of the State of the Art. International Review of Administrative Sciences, 70, 15-31. https://doi.org/10.1177/0020852304041228

[2] Kelly, J.M. (2005) The Dilemma of Unsatisfied Customer in a Market Model of Public Administration. Public Administration Review, 65, 76-84. https://doi.org/10.1111/j.1540-6210.2005.00432.x

[3] Ma, L. (2016) Performance Management and Citizen Satisfaction with the Government: Evidence from Chinese Municipalities. Public Administration, 95, 1-21.

[4] Nigro, H.O. and Císaro, S.E.G. (2016) The Citizen Satisfaction Index: Adapting the Model in Argentine Cities. Cities, 56, 85-90.

https://doi.org/10.1016/j.cities.2016.03.010

[5] Cigu, E. and Constantin, A. (2013) Factors That Impact on Citizen Satisfaction at The Local Level-Case Study on Iasi Municipality. Journal of Public Administration, Finance and Law, 4, 238-243.

[6] Bao, G.X., Dong, J., Lang, M., Wang, H.Q., Zhou, Y.F. and He, W.S. (2010) Experience Exploration and Theoretical Study of Government Performance Evaluation by the Third Party: An Analysis of Gansu Model. Administrative Tribune, 17, 59-67.

[7] Xie, B.F. (2008) People's Evaluation: A Preliminary Study of the New Method in Evaluating the Performance of Chinese Local Party and State Organizations. Beijing University Press, Beijing.

[8] Gao, J. (2012) How Does Chinese Local Government Respond to Citizen Satisfaction Surveys? A Case Study of Foshan City. The Australian Journal of Public Administration, 71, 136-147. https://doi.org/10.1111/j.1467-8500.2012.00760.x

[9] Anderson, E. and Sullivan, M. (1993) The Antecedents and Consequences of Customer Satisfaction for Firms. Marketing Science, 12, 125-143. https://doi.org/10.1287/mksc.12.2.125

[10] Oliver, R.L. (1980) A Cognitive Model of the Antecedents and Consequences of Satisfaction Decisions. Journal of Marketing Research, 17, 460-469. https://doi.org/10.1177/002224378001700405

[11] Roch, C.H. and Poister, T.H. (2006) Citizens, Accountability, and Service Satisfaction the Influence of Expectations. Urban Affairs Review, 41, 292-308. https://doi.org/10.1177/1078087405281124

[12] James, O. (2009) Evaluating the Expectations Disconfirmation and Expectations 
Anchoring Approaches to Citizen Satisfaction with Local Public Services. Journal of Public Administration Research and Theory, 19, 107-123. https://doi.org/10.1093/jopart/mum034

[13] Wu, C.C. (2011) The Impact of Hospital Brand Image on Service Quality, Patient Satisfaction and Loyalty. African Journal of Business Management, 5, 4873-4882.

[14] Bouckaert, G., Van De Walle, S. and Kampen, J.K. (2005) Potential for Comparative Public Opinion Research in Public Administration. International Review of Administrative Sciences, 71, 229-240. https://doi.org/10.1177/0020852305053882

[15] Ryzin, G.G.V., Muzzio, D., Immerwahr, S., Gulick, L. and Martinez, E. (2004) Drivers and Consequences of Citizen Satisfaction: An Application of the American Customer Satisfaction Index Model to New York City. Public Administration Review, 64, 331-341. https://doi.org/10.1111/j.1540-6210.2004.00377.x

[16] Brown, K. and Coulter, P.B. (1983) Subjective and Objective Measures of Police Service Delivery. Public Administration Review, 43, 50-58. https://doi.org/10.2307/975299

[17] Ryzin, G.G.V. (2004) Expectations, Performance, and Citizen Satisfaction with Urban Services. Journal of Policy Analysis and Management, 23, 433-448. https://doi.org/10.1002/pam.20020

[18] DeHoog, R.H., Lowery, D. and Lyons, W.E. (1990) Citizen Satisfaction with Local Governance: A Test of Individual, Jurisdictional, and City-Specific Explanations. Journal of Politics, 52, 807-837. https://doi.org/10.2307/2131828

[19] James, O. (2011) Managing Citizens' Expectations of Public Service Performance: Evidence from Observation and Experimentation in Local Government. Public Administration, 89, 1419-1435. https://doi.org/10.1111/j.1467-9299.2011.01962.x

[20] Ryzin, G.G.V. (2005) Testing the Expectancy Disconfirmation Model of Citizen Satisfaction with Local Government. Journal of Public Administration Research and Theory, 16, 599-611. https://doi.org/10.1093/jopart/mui058

[21] Poister, T.H. and Thomas, J.C. (2011) The Effect of Expectations and Expectancy Confirmation/Disconfirmation on Motorists' Satisfaction with State Highways. Journal of Public Administration Research and Theory, 21, 601-617. https://doi.org/10.1093/jopart/mur004

[22] Morgeson, F.V. (2012) Expectations, Disconfirmation, and Citizen Satisfaction with the US Federal Government: Testing and Expanding the Model. Journal of Public Administration Research and Theory, 23, 289-305.

[23] Lyons, W.E. and Lowery, D. (1989) Citizen Response to Dissatisfaction in Urban Communities: A Partial Test of a General Model. Journal of Politics, 51, 841-868. https://doi.org/10.2307/2131537

[24] Boyne, G., James, O., John, P. and Petrovsky, N. (2009) Democracy and Government Performance: Holding Incumbents Accountable in English Local Governments. Journal of Politics, 71, 1273-1284. https://doi.org/10.1017/S0022381609990089

[25] James, O. and John, P. (2007) Public Management at the Ballot Box: Performance Information and Electoral Support for Incumbent English Local Governments. Journal of Public Administration Research and Theory, 17, 567-580. https://doi.org/10.1093/jopart/mul020

[26] Zeithaml, V.A., Berry, L. and Parasuraman, A. (1993) The Nature and Determinants of Customer Expectations of Service. Journal of the Academy of Marketing Science, 2, 1-12. https://doi.org/10.1177/0092070393211001 
[27] Lupia, A. and McCubbins, M.D. (1998) The Democratic Dilemma: Can Citizens Learn What They Need to Know? Cambridge University Press, Cambridge.

[28] Heinrich, C.J. (2003) Measuring Public Sector Performance and Effectiveness. In: Peters, B.G., Ed., Handbook of Public Administration, Sage, London, 25-37. https://doi.org/10.4135/9781848608214.n3

[29] Moynihan, D.P. (2008) The Dynamics of Performance Management: Constructing Information and Reform. Georgetown University Press, Washington DC.

[30] James, O. and Wilson, D. (2010) Introduction: Evidence from the Comparison of Public Service Performance. Evaluation, 16, 5-12. https://doi.org/10.1177/1356389009350022

[31] Kumasey, A.S. (2014) Service Quality and Customer Satisfaction: Empirical Evidence from the Ghanaian Public Service. European Journal of Business and Management, 6, 172-181.

[32] Parasuraman, A., Zeithaml, V.A. and Berry, L.L. (1988) SERVQUAL: A Multiple-Item Scale for Measuring Consumer Perceptions of Service Quality. Journal of Retailing, 64, 12-40.

[33] Lehtinen, U. and Lehtinen, J.R. (1982) Service Quality: A Study of Quality Dimensions. Service Management Institute, 5, 25-32.

[34] Gronroos, C. (1984) A Service Quality Model and Its Marketing Implications. European Journal of Marketing, 18, 36-44. https://doi.org/10.1108/EUM0000000004784

[35] Seth, N., Deshmukh, S.G., Vrat, P. (2004) Service Quality Models: A Review. International Journal of Quality and Reliability Management, 22, 913-949. https://doi.org/10.1108/02656710510625211

[36] Brady, M.K. and Cronin, J.J. (2001) Some New Thoughts on Conceptualizing Perceived Service Quality: A Hierarchical Approach. Journal of Marketing, 65, 34-49. https://doi.org/10.1509/jmkg.65.3.34.18334

[37] Hsiao, C.T. and Lin, J.S. (2008) A Study of Service Quality in Public Sector. International Journal of Engineering Business Management, 6, 29-37.

[38] Oliver, R.L. (1997) Satisfaction: A Behavioral Perspective on the Consumer. McGraw-Hill, New York.

[39] Cardozo, R.N. (1965) An Experimental Study of Customer Effort, Expectation, and Satisfaction. Journal of Marketing Research, 2, 244-249. https://doi.org/10.1177/002224376500200303

[40] Ho, A.T. (2003) Perceptions of Performance Measurement and the Practice of Performance Reporting by Small Cities. State and Local Government Review, 35, 161-173. https://doi.org/10.1177/0160323X0303500302

[41] Akgul, D. (2012) Measuring the Satisfaction of Citizens for the Services Given by the Municipality: The Case of Kirşehir Municipality. Procedia-Social and Behavioral Sciences, 62, 555-560. https://doi.org/10.1016/j.sbspro.2012.09.092

[42] Stipak, B. (1979) Citizen Satisfaction with Urban Services: Potential Misuse as a Performance Indicator. Public Administration Review, 39, 46-52. https://doi.org/10.2307/3110378

[43] Ryzin, G.G.V. (2007) Pieces of a Puzzle: Linking Government Performance, Citizen Satisfaction, and Trust. Public Performance and Management Review, 30, 521-535. https://doi.org/10.2753/PMR1530-9576300403

[44] Hietbrink, M., Hrtmann, A. and Dewulf, G.P.M. (2012) Stakeholder Expectation and Satisfaction in Road Maintenance. Procedia-Social and Behavioral Sciences, 
48, 266-275. https://doi.org/10.1016/j.sbspro.2012.06.1007

[45] Zhu, Y., Freeman, S. and Cavusgil, S.T. (2018) Service Quality Delivery in a Cross-National Context. International Business Review, 27, 1022-1032.

https://doi.org/10.1016/j.ibusrev.2018.03.002 